\title{
大学の心理教育相談室における学習支援に関する研究 (3)
}

一学習支援が小学生に及ぼす効果一

岡 直樹・児玉真樹子・小島奈々恵・深田博己

(広島大学大学院教育学研究科)

キーワード：学習支援，小学生，心理教育相談室

\begin{abstract}
Educational support at a university's clinic of school psychology (3)
Naoki OKA, Makiko KODAMA, Nanae KOJIMA, and Hiromi FUKADA

(Graduate School of Education, Hiroshima University)

Key words: educational support, school students, clinic of school psychology
\end{abstract}

\section{目 的}

広島大学大学院教育学研究科附属教育実践総合センターで は，現代 GP「子どもの心と学び支援プログラムの展開」の一 環として，地域の小学生（4〜6 年生）に対し，算数に関する 学習支援の提供を行っている。この学習支援は，市川（1993） が提唱する認知カウンセリングの手法に基づき行っている。 また，この学習支援プログラムは，算数の学習支援を行う時 間と遊びの時間の 2 部構成となっている。学習支援プログラ ムへの参加による効果は平成 20 年度前期から毎期検討して いるが (児玉他, 印刷中 $\mathrm{a}$ 等), 本研究では, 平成 21 年度後 期における学習支援が小学生に及ぼす効果を確認する。

\section{方 法}

調查方法・時期 調查対象者は 2009 年 10 月～2010 年 2 月 の間に, にこにこルームで行われた学習支援プログラムに参 加した地域の小学生 15 名 (4 年生 6 名 (男児 2 名、女児 4 名), 5 年生 6 名（男児 3 名、女児 3 名), 6 年生 3 名（男児 2 名、 女览 1 名)）であった。プログラム開始時（10月, 以下 “事 前”と表す）とプログラム終了時（2 月，以下 “事後”と表 す）に，質問紙を用いた集合調査を実施した。質問紙は 2 種 類あり，1 つは事前調査と事後調査で用いる質問紙で，タイ トルは「算数アンケート」であった。質問項目は事前と事後 で同一であった。もう 1 つは事後調査のみで利用する質問紙 で, タイトルが「学習カウンセリングについてのアンケート」 であった。

調査内容「算数アンケート」では, 算数に関する自己効 力感 13 項目と算数に関する学習観 8 項目の 21 項目について 4 段階で評定させた。いずれも得点が高いほど該当項目に当 てはまることを意味した。学習カウンセリングについてのア ンケート」は, 大学生の力量による効果に関する小学生の認 知として, アセスメントによる効果 2 項目, 授業方法・指導 技術による効果 6 項目，先生（学生）との関係 7 項目の計 15 項目, 満足度 3 項目, 算数への関心 - 理解度 3 項目, 遊びへ の関心 1 項目, 学習支援プログラムへの要望 2 項目から構成 された。項目は全て「全くそう思わない（1 点）」から「非常 にそう思う (4 点)」の 4 段階で評定させた。なお, 久損值に はその項目の平均值を代入した。

\section{結 果と考 察}

事前・事後調査の結果の分析「算数アンケート」で測定 した 21 項目を, 小島他 (印刷中a) による因子構造に基づき, 算数に関する自己効力感 (9 項目) と算数に関寸る学習観 $(2$ 項目）の 2 因子に整理し, 各因子の $\alpha$ 係数, 平均, 標準偏差 を算出した（Table 1)。さらに, 因子ごとに事前と事後の得点 に差があるか検討するため，対応のある $t$ 検定を行った。そ の結果，2 因子とも事前と事後で有意差はみられなかった。 平成 20 年度前期（児玉他, 印刷中 a ) と同後期（児玉他, 印 刷中 b）では算数に関する自己効力感については事前と事後 で有意差がみられたものの, 平成 21 年度前期 (小島他, 印刷 中 b）と本研究の平成 21 年度後期ではいずれも有意差がみら れなかった。これより算数に関する自己効力感を向上させ, 学習観を変えさせることの困難さが示唆された。

事後調査の結果の分析「学習カウンセリングについての アンケート」で測定した 24 項目を，小島他 (印刷中 a) によ る因子構造に基づき, 大学生の力量による効果に関する小学 生の認知 2 因子 (コミュニケーション, 理解; 9 項目), 満足 度 1 因子 (3 項目), 算数への関心 1 因子 (3 項目) に整理し, 因子ごとに分析した。各因子の $\alpha$ ，平均值，標準偏差，およ び, 各因子の得点間の相関係数を Table 2 に示した。いずれの 因子の平均值も 3.0 以上と高く $(1 \sim 4$ 点中), 小学生は学習支 援を担当している学生に対する力量を高く評価し，学習支援 を受けたことで本人の算数に対する関心が高まり，満足度も 高かったことが確認された。同様の結果が平成 20 年度前期か ら平成 21 年度前期までの各期の報告（児玉他，印刷中 a 等) でも確認されており，学習支援プログラムが小学生の算数へ の関心の向上に効果があることが示された。また，全因子間 に有意な高い正の相関がみられ，学生の力量による効果を高 く評価しているほど, 小学生本人の算数に対する関心も高く, 当プログラムへの満足度も高くなることが確認された。

Table 1 事前事後調查の各因子の得点

\begin{tabular}{|c|c|c|c|c|c|c|}
\hline & \multicolumn{3}{|c|}{ 事前 } & \multicolumn{3}{|c|}{ 事後 } \\
\hline & $\alpha$ & $M$ & $S D$ & $\alpha$ & $M$ & $S D$ \\
\hline $\begin{array}{l}\text { 算数に関する } \\
\text { 己自己効力感 }\end{array}$ & .77 & 2.84 & .52 & .65 & 3.00 & .45 \\
\hline $\begin{array}{l}\text { 算数に関する } \\
\text { 学習観 }\end{array}$ & .71 & 2. 87 & .99 & .77 & 2.97 & .97 \\
\hline
\end{tabular}

Tab1e 2 事後調查の各因子の得点および因子間の相関係数

\begin{tabular}{|c|c|c|c|c|c|c|c|c|c|c|c|}
\hline & & & \multirow[b]{2}{*}{$\alpha$} & \multirow[b]{2}{*}{$M$} & \multirow[b]{2}{*}{$S D$} & \multicolumn{6}{|c|}{ 各因子の得点間の相関係数 } \\
\hline & & & & & & 1 & & 2 & & 3 & \\
\hline 1 & 学生の力量 & : コミュニケーション & .90 & 3.60 & .51 & & & & & & \\
\hline 2 & による効果 & : 理解 & .70 & 3.54 & .49 & .74 & $* *$ & & & & \\
\hline 3 & 満足度 ～～～～～～～～～ & & .80 & 3. 60 & .59 & .86 & $* * *$ & .75 & $* *$ & & \\
\hline 4 & 算数への関心 & & .84 & 3.36 & .74 & .64 & * & .88 & $* * *$ & 67 & ** \\
\hline
\end{tabular}

注1 ${ }^{* * *} p<.001,{ }^{* *} p<.01,{ }^{*} p<.05$ 